\title{
The New Goods Margin in New Markets
}

\author{
Sang-Wook (Stanley) Cho \\ University of New South Wales \\ Julián P. Díaz \\ Loyola University Chicago, jdiaz17@luc.edu
}

Follow this and additional works at: https://ecommons.luc.edu/business_facpubs

Part of the Business Commons

\section{Author Manuscript}

This is a pre-publication author manuscript of the final, published article.

\section{Recommended Citation}

Cho, Sang-Wook (Stanley) and Díaz, Julián P.. The New Goods Margin in New Markets. Journal of Comparative Economics, 46, 1: 78-93, 2018. Retrieved from Loyola eCommons, School of Business: Faculty Publications and Other Works, http://dx.doi.org/10.1016/j.jce.2017.01.001

This Article is brought to you for free and open access by the Faculty Publications and Other Works by Department at Loyola eCommons. It has been accepted for inclusion in School of Business: Faculty Publications and Other Works by an authorized administrator of Loyola eCommons. For more information, please contact ecommons@luc.edu.

\section{(c) $\odot \ominus$}

This work is licensed under a Creative Commons Attribution-Noncommercial-No Derivative Works 3.0 License. (c) Association for Comparative Economic Studies 2018 


\section{Title: "The New Goods Margin in New Markets"}

Sang-Wook (Stanley) Cho

School of Economics, UNSW Business School, University of New South Wales

Julián P. Díaz

Department of Economics, Quinlan School of Business, Loyola University Chicago

\section{Abstract:}

We analyze the role of the new goods margin in the Baltic countries' exports and imports growth during the 1995-2008 period. Using the methodology developed in Kehoe and Ruhl (2013), we define the set of least-traded goods as those that account for the lowest $10 \%$ of total exports and imports in 1995, and then trace its growth in several markets including the Baltics' main trade partners, the European Union and Russia. We find that, on average, by 2008 least-traded goods accounted for nearly $50 \%$ of total Baltic exports to their main trade partners. Moreover, we find that increases in the share of least-traded exports coincided with the timing of the trade liberalization reforms implemented by the Baltic countries. Leasttraded imports also grew at robust rates, but their growth was lower than that of exports, accounting for slightly less than a quarter of total imports, that is, about half of the exports value. Moreover, we find that the shares of least-traded imports from the EU 15 and from Russia started diverging around the time the Baltic countries joined the EU, with the EU 15 share increasing and the Russian one declining. We also find that the Baltics' share of least-traded exports outpaced that of other economies in Central and Eastern Europe. Finally, exports of new goods from the Baltic countries suffered noticeably during the Global Financial Crisis. After the crisis ended, the restart in new goods exports growth displayed mixed patterns.

JEL classification: F13, F14.

Keywords: economic integration, international trade, extensive margin, new goods margin, Global Financial Crisis. 


\section{Introduction}

The enlargements of the European Union (EU) that granted membership to ten former members of the Eastern Bloc in 2004 and 2007 were watershed events in which the transition economies of Eastern and Central Europe became integrated with Western Europe ${ }^{1}$ Since free trade was one of the key components of EU accession, joining the EU provided new opportunities for trade growth among new and old members.

This increase in trade could occur because countries export and import more of the goods that they had already been trading. But the liberalization of trade could also promote trade in goods that had previously not been traded. In the literature, the former is usually referred to as trade in the intensive margin, while the latter is usually called trade in the extensive margin, or the new goods margin.$^{2}$

What drives the increases of trade in previously non-traded goods? Kehoe and Ruhl (2013) find that growth in the new goods margin of trade is brought about by trade liberalization reforms (such as NAFTA or China's accession to the WTO) and by episodes of deep structural change (such as the one that Korea and Chile underwent during the 1970s and 1980s). Moreover, they also find that increases in the new goods margin are not driven by other factors such as the product cycle or the business cycle. Ruhl (2008) proposes a theory to account for these findings. Following Melitz (2003), Ruhl's model features firms that face entry costs of exporting. Trade liberalization reforms are modeled as permanent changes that raise the profit from exporting and induce firms that were initially non-exporters to begin exporting, thus leading to increases in the new goods margin. This hypothesis is supported by the study of Bernard et al. (2003), who find that US manufacturing firms choose to enter the export market as trade costs fall. Other papers report similar outcomes: Arkolakis (2010), for example, uses market penetration costs to understand the positive correlation between trade liberalization and the number of small exporters in each exporting market.

A number of studies have recently highlighted the importance of the new goods margin during episodes of trade liberalization. This is due to the fact that increases in the extensive margin of both imports and exports have significant implications in terms of welfare and productivity. For example, Broda and Weinstein (2006) quantify the welfare gains resulting from the growth in product variety from US imports for the 1972-2001 period, and estimate the value to American consumers of the expanded import varieties to be $2.6 \%$ of GDP. Thus,

\footnotetext{
${ }^{1}$ Cyprus and Malta also joined the EU in 2004.

${ }^{2}$ To be precise, the "extensive margin" and the "new goods margin" measure similar, but not exactly identical margins of trade. The extensive margin includes both new goods that become traded and previouslytraded goods that stop being traded, whereas the new goods margin only includes new goods that become traded. We explain these differences in more detail in Section 3.
} 
increases in the imports extensive margin have significant welfare consequences. On the export side, in his very influential article, Melitz (2003) shows that reductions in trade barriers increase the profits that firms can earn abroad, and encourages both existing exporters to increase their exports (the intensive margin) and also new firms to begin exporting (the extensive margin). This in turn leads to output and employment being allocated towards exporters, which are highly productive firms, thus raising the average industry productivity. Therefore, if export growth following the liberalization of trade is mainly due to the extensive margin, then increases in productivity can be attributed, at least in part, to increases in trade in new goods.

In this article, we study the patterns of the extensive margin of trade for the case of the three Baltic States: Estonia, Latvia and Lithuania. After gaining independence from the Soviet Union in 1991, these countries implemented a series of extensive market liberalization policies, including aggressive trade liberalization reforms. As they opened their economies to the world, the Baltics experienced rapid trade growth. We ask whether this period of rapid trade expansion also coincided with increases in newly-traded goods by quantifying the relative importance of the new goods margin between 1995 and 2008.

Our choice of the three Baltic countries is motivated by the following facts. First, the Baltic countries went through exactly the kind of economic transformations that Kehoe and Ruhl (2013) identify as the main drivers of extensive margin increases. Second, unlike other Eastern and Central European economies, the Baltics used to be part of the Soviet Union and therefore lacked of any degree of autonomy. Upon independence, they faced a vast array of challenges, most notably among them the difficult task of establishing trade relationships with the rest of the world, which prior to 1991 were determined solely from Moscow. Third, as mentioned previously, from the onset of the transition, the three countries became leading reformers among the formerly centrally-planned economies and quickly underwent market reform transformations with success. Indeed, the term "Baltic Tigers" was coined to highlight the rapid economic growth experienced by the Baltic countries, in contrast to the economic and political crises that have plagued other regions, such as the countries of the former Yugoslavia. Lastly, as former Soviet republics, the Baltic nations had sizable portions of ethnic Russian-speaking population, most of which remained in the Baltics even after their independence. Thus, in principle, this gives the Baltic countries a unique potential to better tap into the Russian market.

In our empirical analysis, we assess the role of the Baltic new goods margin with a number of trade partners. In particular, we choose the EU (taken as the single bloc made up of the 15 countries prior to its expansion in 2004), as well as some of its individual members such as Germany, Sweden and Finland, since they are among the most important Baltic trade 
partners. We also study the new goods margin with Russia, given the historical ties between the Baltic states and Russia. Besides our benchmark analysis, we extend our investigation to test whether the increase in the new goods margin with the EU and Russia was unique to the Baltic countries, or instead it was a generalized fact across the transition economies. Finally, we also extend our period of study up to 2014 to determine whether the large collapse in international trade during the Global Financial Crisis (GFC) of 2009 had any impact on the new goods margin in the exports of the region.

Our study employs the methodology recently developed by Kehoe and Ruhl (2013) (henceforth KR), who rank goods from smallest to largest by their trade values in the base year and accumulate the ordered goods to form ten sets or bins, each containing $10 \%$ of total trade. The goods in the first set are labeled as "least-traded goods," since they represent the goods with the lowest trade values ${ }^{3}$ We believe KR's approach of defining least-traded goods by using a threshold that takes into account the relative - rather than absolute - importance of a good in total trade is the appropriate one to adopt in an investigation like the one we conduct. Other studies, most notably among them Evenett and Venables (2002), use a fixed amount to classify a good as being not traded (for example, $\$ 50,000)$. But using arbitrary absolute thresholds is problematic given the large variation in total trade values among countries. In particular, for small economies or economies with small aggregate trade volumes, such a threshold can imply a completely different relative importance of a good labeled as not-traded and would result in very few goods being traded. Since Estonia, Latvia and Lithuania are among the smallest countries in Europe, this issue is of particular importance and leads us to choose KR's methodology over other potential techniques $\stackrel{4}{4}^{4}$

The contribution of our paper is to provide answers to a set of specific questions: How do trade liberalization reforms affect export and import trends? Do these reforms deepen existing trade relationships or do they encourage new trade opportunities? Our analysis is also informative to policymakers who can devise strategies that are conducive to promoting new exports to new markets. Furthermore, our paper allows us to document the interesting case of previously-closed economies that quickly opened to trade, and understand whether such economies tend to specialize in trading a relatively small set of products, or instead they expand the variety of goods that they purchase from and sell to the rest of the world.

Our main findings are as follows: first, we find strong increases in the share of previously

\footnotetext{
${ }^{3}$ Note that the set of least-traded group contains both goods with zero trade value and with positive, but small, values.

${ }^{4}$ Even within the Baltic countries there is a wide variation in trade volumes, with Lithuania's merchandise trade being, on average, 40\% larger than Estonia's and almost 100\% larger than Latvia's.
} 
non-traded or least-traded goods between 1995 and 2008, a period that for the Baltic countries entailed transformational changes such as accession into the EU. The set of goods that in 1995 constituted the bottom $10 \%$ of Baltic exports to their main trade partners jumped to nearly $50 \%$ in 2008. Moreover, the share of least-traded exports exhibited increases that coincide with the timing of the major trade liberalization reforms implemented by the Baltics. Second, least-traded imports into the Baltics also displayed significant growth, but on average the magnitudes were at most half the values of their exports counterparts. Additionally, we find that the shares of least-traded imports from the EU 15 and from Russia started diverging around the time the Baltic countries joined the EU, with the EU 15 share increasing and the Russian one declining.

Third, we find that the Baltic share of least-traded exports outpaced that of other economies in Central and Eastern Europe such as the Czech Republic, Hungary and Poland. For example, least-traded exports to the EU 15 and Germany accounted for approximately $40 \%$ and $53 \%$ of average Baltic exports in 2008, respectively. The corresponding shares for the non-Baltic countries were significantly lower: $22 \%$ for the EU 15 and $21 \%$ for Germany. In addition, we find that the majority of the non-Baltic countries' exports were driven by the intensive margin, whereas the extensive margin played a more important role for the Baltic countries.

Finally, we look at the behavior of the new goods margin during the Global Financial Crisis. Due to the unprecedented and widespread nature of this economic downturn, exports of new goods from the Baltic countries also suffered significantly between 2008 and 2011. After the crisis ended, the restart in new goods export growth displayed mixed patterns, with least-traded exports to the EU resuming growth and new goods exports to Russia declining.

The methodology in Kehoe and Ruhl (2013) has been previously employed to analyze the role of the extensive margin in other trade liberalization episodes. For example, Sandrey and Van Seventer (2004) measure the growth of new goods exports from New Zealand to Australia after the Closer Economic Relations Trade Agreement between the two countries was enacted in the mid 1980s, and find that, on average, the relative importance of the new goods doubled for the 1988-2003 period. Amarsanaa and Kurokawa (2012) focus on the period of structural reforms in Mongolia and find evidence of large increases in the extensive margin of trade with its major trade partners, including instances when the leasttraded goods ended up accounting for $100 \%$ of the total Mongolian exports to a subset of countries. Dalton (2014) documents China's exports and imports of least-traded goods to and from Japan following its accession into the World Trade Organization (WTO) in the early 2000s, and also finds increases in the extensive margin, although they are of smaller magnitudes than the ones we find for the case of the Baltic countries. Similarly, Dalton 
(2016) focuses on the behavior of Austrian new goods exports and imports to and from the new EU entrants. Finally, Hloušek (2010) analyzes the changes in the extensive margin for the Visegrad ${ }^{5}$ countries' exports to the EU 15 bloc and finds increases in least-traded goods for all four countries, although they are of smaller magnitudes than the ones we document for the Baltics. Hloušek's work, however, restricts its attention to the 1993-2006 or 19972006 periods, thus potentially missing the delayed effect on trade flows generated by the 2004 EU expansion. Although all these studies share a common methodology and relatively comparable qualitative results, our work stands apart because all previous papers deal with countries that were, in one way or another, previously engaged in international trade, while the Baltic countries did not have trade relationships with the rest of the world prior to their independence from the Soviet Union.

The rest of the paper is organized as follows. Section 2 presents an overview of the trade liberalization reforms implemented in the Baltics since their independence. Section 3 describes the methodology we employ in our analysis, the data we work with, and the selection of trade partners. Section 4 describes the main results for least-traded exports and imports. In Section 5 we extend our analysis by conducting a cross-regional comparison and by including the Global Financial Crisis period. Section 6 discusses the main results of our analysis and Section 7 concludes.

\section{Trade Liberalization in the Baltics6}

After regaining their independence in 1991, Estonia, Latvia and Lithuania decisively embraced trade liberalization. Although the speed and extent of the trade reforms were uneven across the Baltic states, they were implemented in a more aggressive manner than the other countries in Central and Eastern Europe, even though their transition to market economies started earlier. The trade liberalization reforms encompassed several dimensions: unilateral, bilateral and multilateral.

At the individual level, Estonia was the country that implemented the most aggressive trade liberalization reforms among the three Baltic states, including a unilateral removal of import tariffs. By 1993, the average weighted Estonian tariff rate was below $2 \%$ and by 1997 it was reduced to zero, including agricultural goods. The trade liberalization reforms in Latvia and Lithuania were also substantial, but not as far-reaching as in the case of Estonia.

\footnotetext{
${ }^{5}$ The Visegrad countries is a group of four Central European states: Czech Republic, Hungary, Poland and Slovakia.

${ }^{6}$ This section is based on the findings in Feldmann (2001), Feldmann and Sally (2002), Vilpišauskas (1998), Vilpišauskas (2003) and Pautola-Mol (2003).
} 
On the bilateral level, in September 1993 the three countries signed the Baltic Area Free Trade Area (BAFTA), which came into effect in April 1994 and by July 1998 had removed all non-tariff barriers to trade, thus creating a virtually frictionless trade area. The Baltic countries also independently negotiated free trade agreements with the European Free Trade Association, Bulgaria, the Czech Republic, Hungary, Poland, Slovakia, Slovenia, Turkey and Ukraine. These agreements were of particular importance to secure market access for Estonia, given that it had unilaterally removed import tariffs.

On the multilateral track, the Baltic countries sought to liberalize their foreign trade by applying for accession to the World Trade Organization. Latvia started negotiations in 1993 and Estonia in 1994; they both became WTO members in 1999. Lithuania applied for accession in 1994 and gained membership in 2001. The Estonian case was quite unique because, in anticipation to EU accession, it wished to bind tariffs in the WTO at levels above the rates it applied at the time of negotiations (which were basically zero).

However, among all the external liberalization efforts the Baltic states pursued, accession into the EU was the most coveted objective, not only because of its economic implications, but its geopolitical ones as well. Membership into the EU first started with the bilateral free trade agreements Estonia, Latvia and Lithuania signed with the EU in July 1994, and entered into force in January 1995. The free trade agreements mandated the gradual removal of trade restrictions and envisioned an eventual free trade area. These free trade agreements were replaced by the Association Agreements each country signed in June 1995 and entered into effect in February 1998. These Association Agreements included additional economic cooperation and increased political dialogue between the two parties.

The signing of the Association Agreements encouraged the Baltic countries' demands for accession into the EU. In 1996, the European Commission recommended to start accession negotiations with Estonia, but not with Latvia or Lithuania. Latvia and Lithuania would not start their own negotiations until February 2000. It was ultimately decided that all three countries would join the EU at the same time, during the 2004 expansion that granted membership to the Baltic countries and seven other nations in Central and Eastern Europe and the Mediterranean. By becoming EU members, the Baltic countries were required to abandon their individual external trade policies and replace them with the EU's Commercial Common Policy. Consequently, the Baltics completely liberalized trade with the other members of the EU, but at the same time increased the level of tariffs they would have to apply to industrial and agricultural goods originating from outside the EU, given the Baltics' less protectionist stance prior to EU accession (especially in the case of Estonia, which had unilaterally eliminated its import duties). 


\section{Methodology}

\subsection{Data}

We use detailed bilateral merchandise trade data extracted from the World Bank's World Integrated Trade Solution (WITS) database, reported on annual frequency. We focus on the 1995-2008 period, a span that includes the years when the trade liberalization and structural reforms where implemented, as documented in Section 2. The choice of 1995 as the initial year in our sample is due to two factors: first, the WITS trade data is not available for all the three countries prior to 1995. Second, as Bems and Jönsson Hartelius (2006) point out, 1995 is the first year in which the Baltic countries can be appropriately considered as open economies. Similarly, we limit our analysis up to 2008, to isolate our results from the effects of the Global Financial Crisis.7 The data we use is disaggregated at the 5-digit level of the Standard International Trade Classification (SITC) Revision 2 code. This implies that our analysis includes a total of 1836 goods.

\subsection{Defining Least-traded Goods}

To construct a measure of the new goods margin in international trade, we employ the methodology developed by Kehoe and Ruhl (2013), who define the set of least-traded goods as the group of commodities that were initially traded in low volumes or not traded at all. More precisely, for each good Kehoe and Ruhl first compute the average trade value (either exports or imports) during the first three years in the sample (in our case, we average the values for 1995 to 1997). Next, goods are sorted in ascending order according to the threeyear average. Finally, the cumulative value of the ranked goods is grouped into 10 bins, each containing $10 \%$ of total trade. The basket of goods in the bottom decile (or the bottom $10 \%$ of total bilateral trade value) is labeled as the "least-traded" goods, or the "new" goods. By construction, the least-traded goods set includes all the goods that recorded zero trade volume, as well as some goods that recorded positive but low volume of trade 8 With goods grouped in 10\% sets, we can trace the growth of trade value for each bracket between 1995 and 2008, paying particular attention to the bottom decile, which represents the growth of trade of the least-traded goods, or the "new goods margin."

\footnotetext{
${ }^{7}$ In the sensitivity analysis section, we extend our period of analysis to 2014, to understand the impact of the trade contraction caused by the GFC on the Baltic new goods margin.

${ }^{8}$ Note that the resulting cutoff value that defines the least-traded goods in the KR methodology is specific to the country pair and the trade flow direction, and differs from thresholds with fixed-dollar amounts used by others in the literature. For example, Feenstra (1994) and Hummels and Klenow (2005) use $\$ 0$ as the threshold for traded/non-traded goods, whereas Evenett and Venables (2002) use \$50,000. In the Appendix, we find that our qualitative findings remain unchanged when we use an alternative fixed-value cutoff.
} 


\subsection{Decomposition of Trade Growth: Extensive and Intensive Margins}

The "new goods" methodology allows us to trace the changes in the relative importance of the goods in the bottom decile, but does not provide information on the contributions of the extensive and intensive margins to overall trade growth, since it only focuses on the shares of each bracket in total exports or imports and not on the changes in trade volumes. More specifically, the least-traded goods methodology only considers new products being exported or imported at the margin. On the other hand, the concept of the extensive margin should include not only new entrants contributing to the new goods margin, but also some previously-traded goods that exit the market over time. Thus, to complement our analysis, we also decompose the growth of trade into extensive and intensive margins, to further understand their relative importance in total trade growth.9 To do so, we follow the methodology used by Kehoe and Ruhl (2013), which in turn is adapted from Hummels and Klenow (2005).

We summarize trade decomposition methodology briefly. Consider the growth in trade for a specific country-pair between time $t$ and $s$ for $s \geq t$. We use $i \in\{1,2, \ldots, n\}$ to denote a good in $\mathrm{G}$, the set of all goods in both periods. Moreover, $x_{i, t}$ represents the trade value (exports or imports) of good $i$ in year $t$, and $\bar{x}_{t}$ is defined as the cutoff value for goods to be included in the set of the least-traded goods, that is, $\bar{x}_{t}$ is the trade value of the last good to be included in the bottom decile in period $t$. Consequently, a good $i$ is labeled as "least-traded" if $x_{i, t} \leq \bar{x}_{t}$. Let $\mathrm{G}_{\mathrm{T}}(\mathrm{t})$, a subset of $\mathrm{G}$, denote the basket of the goods in year $t$ that are not in the basket of least-traded goods in year $t$ (that is, all goods such that $\left.x_{i, t}>\bar{x}_{t}\right)$. Similarly, $\mathrm{G}_{\mathrm{T}}(\mathrm{s})$ is the set of goods in year $s$ that recorded trade volumes in excess of $\bar{x}_{t}$, or $x_{i, s}>\bar{x}_{t}$. Thus, $\mathrm{G}_{\mathrm{T}}=\mathrm{G}_{\mathrm{T}}(\mathrm{t}) \cap \mathrm{G}_{\mathrm{T}}(\mathrm{s})$ contains the goods that are traded in excess of $\bar{x}_{t}$ in both years. With this notation, the growth of trade between years $t$ and $s$ is:

$$
1+\gamma=\frac{\sum_{i \in \mathrm{G}} x_{i, s}}{\sum_{i \in \mathrm{G}} x_{i, t}}
$$

where $\gamma$ is the growth rate of trade. We define the growth rate of the intensive margin of trade as the growth of trade in the goods that belong to $\mathrm{G}_{\mathrm{T}}$ (or the trade growth in goods that were traded more than $\bar{x}_{t}$, in both years):

$$
1+\gamma_{I M}=\frac{\sum_{i \in \mathrm{G}_{\mathrm{T}}} x_{i, s}}{\sum_{i \in \mathrm{G}_{\mathrm{T}}} x_{i, t}}
$$

\footnotetext{
${ }^{9}$ In what follows, due the different focuses of the two measures, we will use the term new goods margin to refer to changes in exports or imports shares accounted for by the least-traded goods (as defined in Section 3.2 , while we will employ term extensive margin in the context of the trade growth decomposition analyses.
} 
Taking the ratio of (1) and (2), the extensive margin of trade growth is defined as the residual of total trade growth not accounted for by the intensive margin:

$$
\begin{aligned}
1+\gamma_{E M} & =\left[\frac{\sum_{i \in \mathrm{G}} x_{i, s}}{\sum_{i \in \mathrm{G}} x_{i, t}}\right] /\left[\frac{\sum_{i \in \mathrm{G}_{\mathrm{T}}} x_{i, s}}{\sum_{i \in \mathrm{G}} x_{i, t}}\right] \\
& =\frac{1+\gamma}{1+\gamma_{I M}}
\end{aligned}
$$

Finally, taking logarithms on both sides of (3) and expressing the growth rate of total trade as relative shares of the intensive and extensive margins: 10

$$
\begin{aligned}
\log (1+\gamma)= & \log \left(1+\gamma_{I M}\right)+\log \left(1+\gamma_{E M}\right) \\
1= & \frac{\log \left(1+\gamma_{I M}\right)}{\log (1+\gamma)}+\frac{\log \left(1+\gamma_{E M}\right)}{\log (1+\gamma)} \\
& \text { (intensive margin share) (extensive margin share) }
\end{aligned}
$$

\subsection{Trade Partners}

\begin{tabular}{|c|c|c|c|c|c|c|c|c|}
\hline \multirow[b]{2}{*}{ Partner } & \multicolumn{2}{|c|}{ Estonia } & \multicolumn{2}{|c|}{ Latvia } & \multicolumn{2}{|c|}{ Lithuania } & \multicolumn{2}{|c|}{ Average } \\
\hline & Exports & Imports & Exports & Imports & Exports & Imports & Exports & Imports \\
\hline EU 15 & 54.3 & 46.0 & 52.5 & 51.5 & 43.7 & 43.7 & 50.1 & 47.1 \\
\hline Germany & 6.5 & 9.6 & 12.8 & 16.4 & 13.4 & 16.3 & 10.9 & 14.1 \\
\hline Sweden & 13.3 & 6.7 & 9.3 & 6.8 & 4.0 & 3.4 & 8.9 & 5.6 \\
\hline Finland & 20.7 & 14.8 & 2.5 & 7.7 & 1.3 & 3.0 & 8.2 & 8.5 \\
\hline United Kingdom & 3.5 & 2.5 & 12.5 & 2.5 & 5.2 & 2.9 & 7.1 & 2.6 \\
\hline Netherlands & 2.6 & 2.1 & 2.9 & 3.7 & 3.4 & 3.2 & 3.0 & 3.0 \\
\hline Other Baltics & 12.6 & 4.0 & 16.7 & 14.8 & 11.4 & 5.5 & 13.6 & 8.1 \\
\hline Russia & 11.8 & 9.0 & 10.8 & 10.4 & 15.0 & 24.2 & 12.5 & 14.5 \\
\hline United States & 2.0 & 2.8 & 2.8 & 1.7 & 2.6 & 2.4 & 2.5 & 2.3 \\
\hline
\end{tabular}

Table 1 shows the share of exports and imports of the main trade partners for each Baltic country. We use this information to guide our choice of trade partners in our analysis.

Table 1. Baltic Countries' Trade Partners

(percent of total merchandise exports and imports, 1995-2008 averages)

First, we choose the 15-country bloc that constituted the European Union prior to the 2004 expansion, due to its importance in total trade for the Baltic countries 11 In what follows, we refer to this group as the "EU 15."

\footnotetext{
${ }^{10}$ Note that these shares are not restricted to take values between 0 and 1.

${ }^{11}$ The 15 members are: Austria, Belgium, Denmark, Finland, France, Germany, Greece, Ireland, Italy, Luxembourg, Netherlands, Portugal, Spain, Sweden and the United Kingdom.
} 
In addition to the EU 15, we also look at subset of its member countries. Germany stands out because it is by far the largest trade partner within the EU for Latvia and Lithuania. Similarly, Finland and Sweden are the two largest trade partners for Estonia. We combine those last two countries into a single group, which we refer to as the "Nordics."

Finally, we choose Russia because of its historical ties to the Baltic countries and because it is one of their largest trade partners. Indeed, between 1995 and 2008 Russia accounted for large shares of merchandise imports and exports to and from Estonia and Latvia, and was the largest merchandise trade partner of Lithuania. In addition, trade relations with Russia evolved unevenly across the individual Baltic countries. Prior to the 2004 EU Baltic accession, Estonia and Latvia did not receive Most Favored Nation (MFN) treatment from Russia, while Lithuania did. However, once the Baltic countries joined the EU, the bilateral trade relationships were replaced by the common trade policy between the EU and Russia. Since the EU and Russia had an existing agreement to remove trade barriers under the Common Economic Space agreement, joining the EU provided for better access to the Russian market for Estonia and Latvia, facing lower tariffs.

\section{Benchmark Results}

For ease of the exposition, the results below refer to the average Baltic exports and imports of least-traded goods, rather than the trade flows of each individual Baltic economy. In the Appendix, we present detailed least-traded goods data for each individual Baltic country.

\subsection{The Evolution of Least-traded Exports: 1995-2008}

Finding 1: The Baltic countries recorded strong growth in least-traded exports, which by 2008 accounted for nearly half of all exports to their main trade partners.

In Figure 1 we document the distribution of average Baltic exports to the EU 15, Germany, the Nordics, and Russia for the 1995-2008 period. The horizontal axis depicts the cumulative fraction of 1995 exports value split in $10 \%$ brackets, while the vertical axis displays the corresponding fraction in 2008. The height of each column indicates how much the basket of goods in each bin accounts for the trade value in 2008. For instance, the set of the least-traded exports to the EU 15 in 1995 (which comprised the lowest 10\% of average Baltic exports to the EU 15) makes up 39.8\% of the total exports to the EU 15 in 2008. To facilitate comparisons, we include a horizontal line at the $10 \%$ value in the vertical axis. Thus, if a column exceeds the horizontal line, this means that the trade of the goods contained in that set was higher than the average trade growth. Hypothetically, if all bars were 
aligned exactly at the horizontal line, it would mean that trade growth across all brackets was uniform, with no changes in relative shares.

For all the export destinations we consider, we find significant increases in the leasttraded goods share of total exports. As previously mentioned, for the case of the EU 15, the fraction of least-traded exports jumped from 10\% in 1995 to nearly $40 \%$ in 2008. Looking at the individual main EU trade partners, growth in least-traded exports was even larger, accounting for nearly $53 \%$ and $49 \%$ of total exports to Germany and the Nordic countries, respectively.

Figure 1. Composition of Baltic Exports

Composition of Baltic Exports

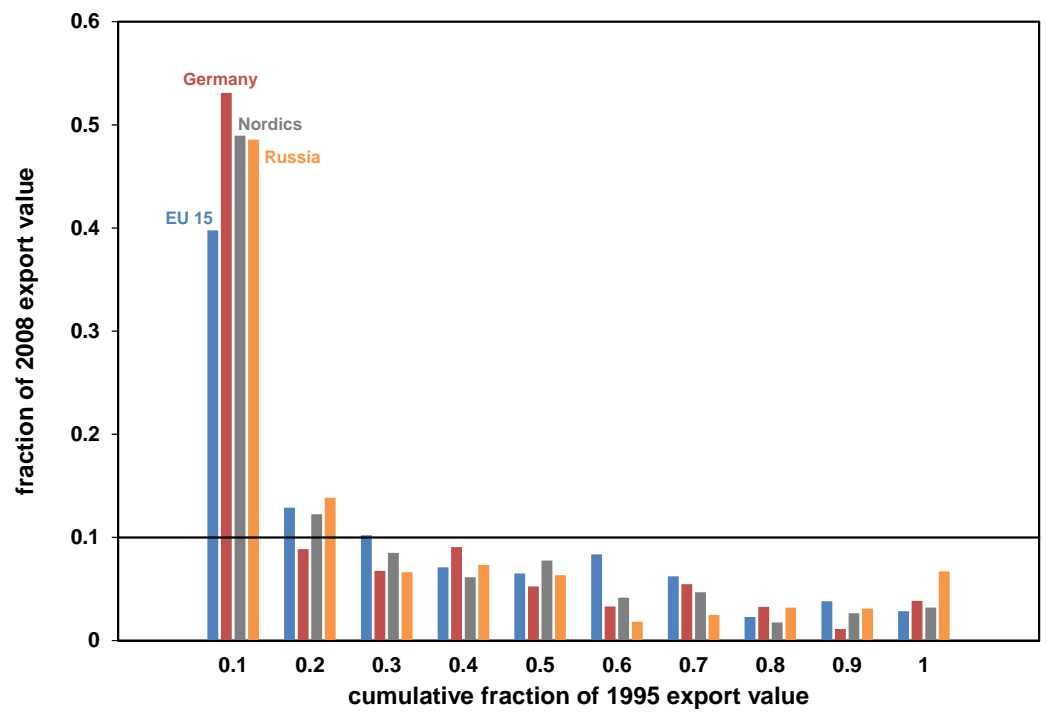

Since the trade liberalization policies implemented by the Baltic countries had an intraregional and EU-oriented focus, a pertinent question is whether the new goods margin growth happened mostly with EU partners at the expense of other major non-EU countries, namely, Russia. Despite their Western-oriented trade policies, we find that least-traded exports to Russia grew at comparable rates. Indeed, when averaged across the three Baltic economies, the share of least-traded exports to Russia grew from 10\% in 1995 to $49 \%$ in 2008.

Finding 2: The share of least-traded Baltic exports to their main trade partners exhibits increases that coincide with the timing of the major trade liberalization reforms they implemented.

Figure 1 displays the distribution of exports in two points in time (1995 and 2008), but does not capture the movements of least-traded exports over time. It could well be the case that 2008 was an anomalous year and does not reflect a generalized trend. Thus, we document the evolution of least-traded exports during our period of analysis. In particular, we are interested in finding whether the exports of the least-traded goods were affected by 
the various trade liberalization events experienced by the Baltic countries, and whether the pace of least-traded export growth differs across the destinations of their exports. These trends are depicted in Figure 2.

Figure 2. Least-traded Goods Exports (1995-2008)

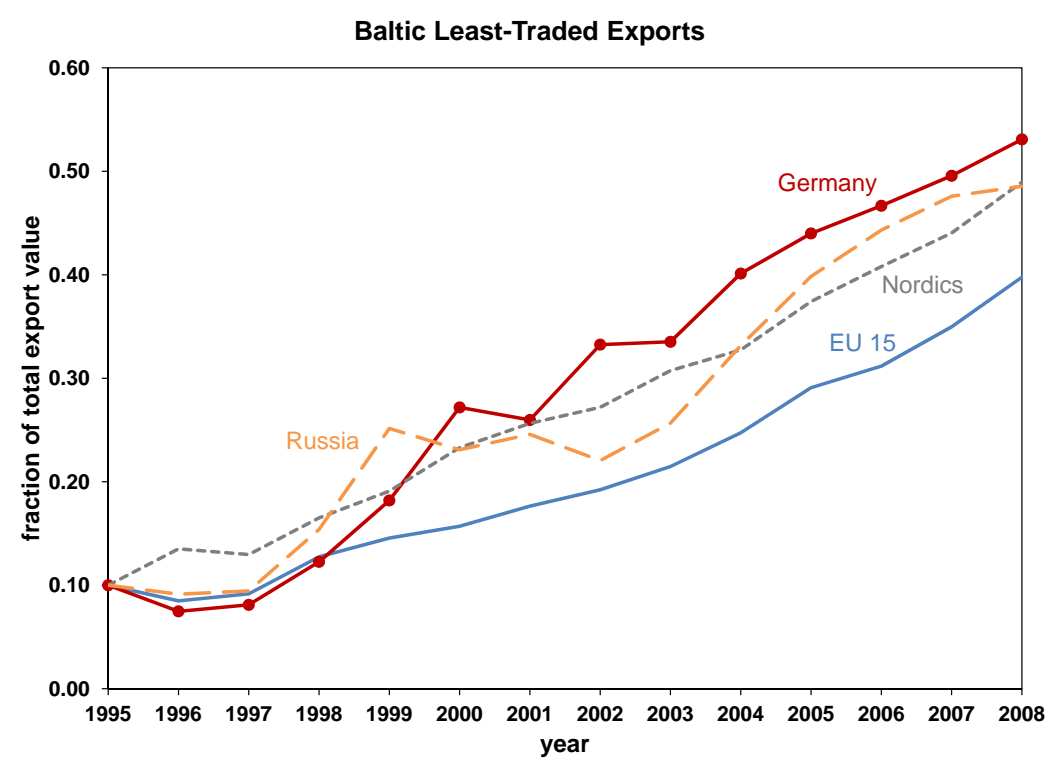

We find that the share of least-traded exports to the EU 15 and its member countries grew at a relatively consistent pace throughout the whole sample period. A deeper look reveals that least-traded exports to the EU 15 grew at the fastest rate between 2002 and 2005, when its share grew from $19 \%$ to $29 \%$. For the main trade partners within the EU, least-traded exports toward Germany and the Nordic countries display noticeable "jumps" around the late 1990s and mid 2000s. Thus, the faster growth in least-traded exports destined to the EU coincided with the periods when the Association Agreements and accession into the EU entered into effect.

During this same period, least-traded exports to Russia, which initially had been growing at a similar rate as the least-traded exports to the top EU trade partners, stagnate in the late 1990s and early 2000s. This suggests that as the Baltic countries received preferential treatment from the EU, they were able to increase their export variety mix in that market at the expense of the Russian market. New goods exports to Russia only resume growth after the Baltics' accession in the EU. The timing in this increase points out the indirect benefit of joining the EU, which automatically provided preferential treatment for Estonian and Latvian exports into the Russian market, such as MFN status. 


\subsection{The Evolution of Least-traded Imports: 1995-2008}

Finding 3: Least-traded imports into the Baltic countries also display significant growth, but their magnitudes are at most half the values of their exports counterparts.

The Baltic countries also recorded rapid growth in their imports of least-traded goods. However, the role of least-traded imports is of a much smaller scale when compared to the case of exports, especially with their main trade partners. In particular, least-traded imports from the EU 15, Germany and the Nordic countries grew at a pace that was roughly half the one observed for Baltic exports of least-traded goods to those same markets.

Figure 3 depicts least-traded imports from the EU 15. While in 1995 they accounted for $10 \%$ of total EU 15 imports by the Baltic countries, by 2008 they had increased to an average of $22 \%$, about half of its exports counterpart. Similarly, new goods imports from Germany and the Nordics experienced a marked increase between 1995 and 2008, going from $10 \%$ to around $27 \%$ and $23 \%$, respectively. However, this growth is again about half the one recorded by Baltic exports of least-traded goods to those same countries.

Figure 3. Composition of Baltic Imports

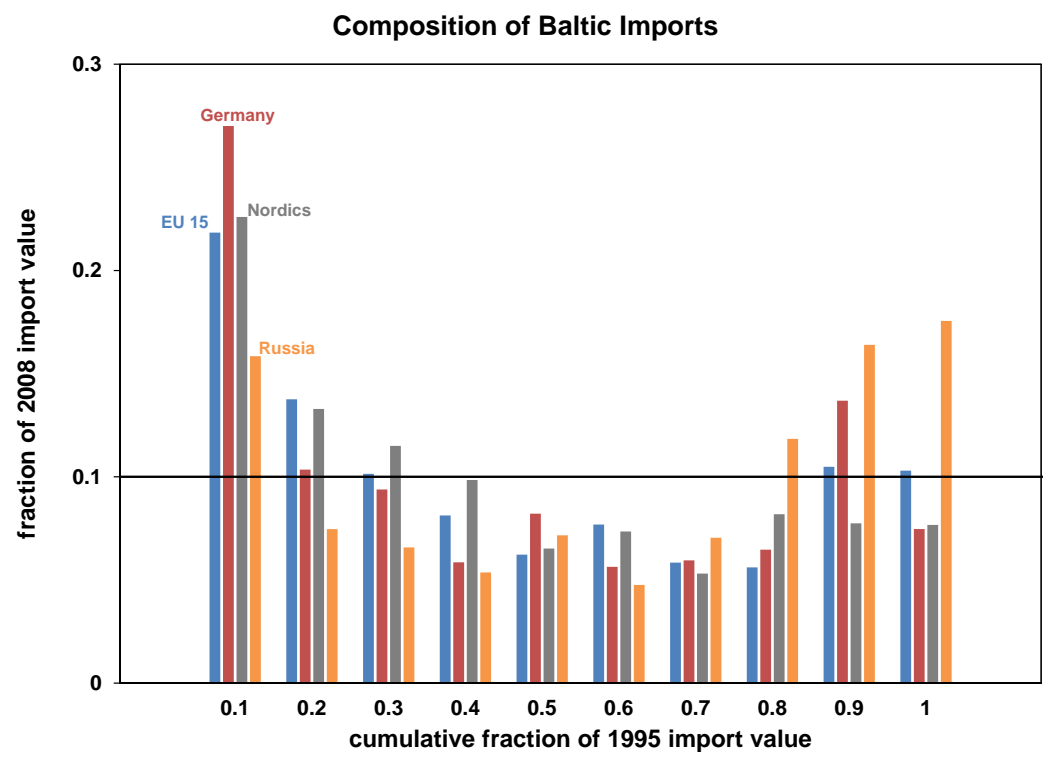

Least-traded imports from Russia also registered lower growth than exports, accounting for $16 \%$ of total Russian imports in 2008. This is roughly one third of the increase recorded by least-traded exports to Russia. In fact, the distribution of imports from Russia shows that sizable growth took place in the goods that had been previously traded (mainly petroleum), as shown in the growth of the top two decile brackets.

Turning to the time series, as depicted in Figure 4, the share of least-traded imports from the EU 15 showed a persistent but smooth increase from 1995 to 2008, without re- 
markable surges in any particular year. Moreover, when focusing on the individual EU members, we find that the shares of least-traded imports from Germany and the Nordics show steep increases between 1997 and 2000, a period which includes the years of the Association Agreements coming into effect. After stabilizing for a couple of years, these shares started increasing again after 2004, the year of Baltic accession into the EU.

Figure 4. Least-traded Goods Imports (1995-2008)

Baltic Least-Traded Imports

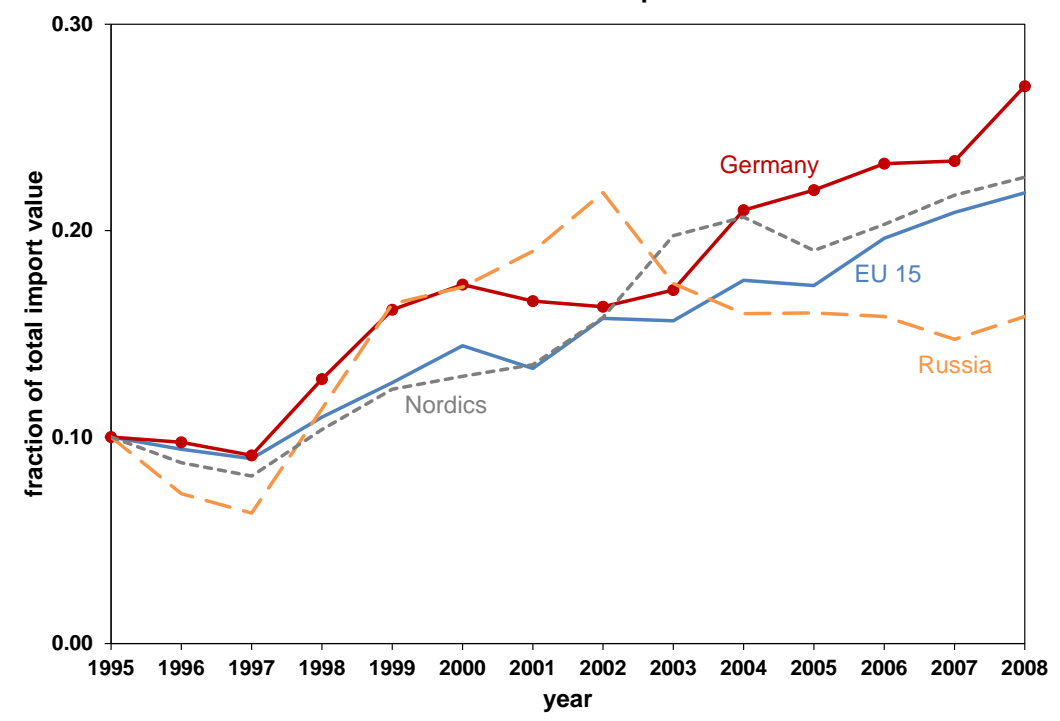

Finding 4: As the Baltic countries joined the EU, least-traded imports from and exports to Russia show divergent patterns, with least-traded exports resuming growth and least-traded imports declining.

As we documented in Section 4.1, least-traded exports to Russia, which had stagnated for a number of years, restarted growing around the time the Baltics joined the EU and gained preferential treatment from Russia as EU members. On the other hand, the evolution of least-traded imports from Russia showed an opposite pattern. Least-traded imports were on the rise until 2002, but that trend reverted starting from 2003, with least-traded imports from Russia experiencing a continuous decline ever since. This change in imports patterns can be attributed to the trade diversion effect generated by the Baltic countries joining the EU customs union in 2004: prior to their accession into the EU, the Baltics' tariffs were in general low. Upon EU accession, the Baltics had to adopt the EU's Commercial Common Policy, which eliminated trade restrictions among EU members but, from the perspective of the Baltic countries, increased tariffs on non-EU imports, thus discouraging Russian new goods imports. 


\subsection{Decomposition of Trade Growth and the Role of the Extensive Margin}

In this section we examine the role of the extensive margin in exports and imports growth, using the decomposition methodology outlined in Section 3.3.

Finding 5: The share of the extensive margin of Baltic exports is similar between the EU (and its member countries) and Russia. While the extensive margin plays a smaller role in imports than in exports, we find that the share of the extensive margin is larger for EU imports than for Russian imports.

Table 2 presents the growth rate of total Baltic exports (in nominal terms) between 1995 and 2008, as well as the share of the extensive margin. We find that the growth rates of Baltic exports to the EU 15 and Russia between 1995 and 2008 were quite high and similar in magnitude. In addition, there are no large variations in the share of the extensive margin when we compare the two markets. As for the case of the individual EU members, the share of the extensive margin was as high as $23 \%$ for the German market and $22 \%$ for the Nordic countries 12

Table 2. Exports Growth and the Share of the Extensive Margin (percent)

\begin{tabular}{ccc}
\hline & Total Export Growth & Share of Extensive Margin \\
\hline EU 15 & 488.2 & 12.2 \\
Germany & 313.9 & 23.4 \\
Nordics & 612.5 & 21.7 \\
Russia & 486.2 & 12.3 \\
\hline
\end{tabular}

Switching to imports growth, we present our results in Table 3. For all the main trade partners except for the Nordic countries, the growth rates of imports exceeded those of exports. On the other hand, the fraction of imports growth that can be attributed by the extensive margin was consistently lower than the corresponding figures for exports, rarely surpassing the two-digit mark, which was the norm for the case of exports. For the EU 15, Germany and the Nordic countries, only around $2-4 \%$ of the total trade growth was due to the extensive margin, a value significantly lower than the contribution of the extensive margin from the export side. For imports from Russia, the share of the extensive margin is in fact negative at $-18 \%$, implying that Russian imports were dominated by existing imports rather than by new goods.

\footnotetext{
${ }^{12}$ The growth in total exports of each individual Baltic country was quite similar, in particular for exports to the EU 15. In spite of these similarities in overall growth, the role of the extensive margin shows a different story: export growth due to the extensive margin in Estonia lagged its counterparts in Latvia and Lithuania for most destinations, except for Russia. More details are provided in Appendix 1.
} 
Table 3. Imports Growth and the Share of the Extensive Margin

(percent)

\begin{tabular}{ccc}
\hline & Total Import Growth & Share of Extensive Margin \\
\hline EU 15 & 595.8 & 3.9 \\
Germany & 663.6 & 3.6 \\
Nordic & 387.2 & 2.0 \\
Russia & 504.4 & -17.5 \\
\hline
\end{tabular}

\section{Additional Analyses}

\subsection{Cross-Regional Comparison}

Our previous results documented significant increases in Baltic exports of new goods, and that a sizable fraction of Baltic total export growth can be attributed to newly-traded goods. We also found that this pattern holds for both EU countries as well as for non-EU countries such as Russia. In this section, we ask whether the export growth along the new goods margin is a unique feature of the Baltic countries, or instead a generalized trend throughout the transition economies. More specifically, we compare the patterns of least-traded goods trade observed in the Baltics with those in other major transition economies in Central Europe: the Czech Republic, Hungary and Poland ${ }^{13}$

Finding 6: The new goods margin in exports played a much larger role for the Baltic countries than for other transition economies, with a larger variety of goods exported to its main trade partners. Moreover, exports of new goods from the Baltics to the EU continued growing at a robust rate after joining the EU, while it came to a halt after EU accession for the non-Baltic economies in our sample.

In Table 4 we show the average Baltic and non-Baltic share of least-traded exports in 2008. An immediate result is that the share of least-traded exports is consistently higher for the Baltic countries than for the non-Baltic countries, for all the export destinations we consider. Looking at total world exports and exports to the EU 15, the Baltics' share of least-traded goods in 2008 increased to approximately $30 \%$ and 40\%, respectively. On the other hand, over the same period, the non-Baltic average increase in the fraction of leasttraded goods was roughly half of the observed values in the Baltic countries. For the main

\footnotetext{
${ }^{13}$ For those non-Baltic countries, Hloušek (2010) reports the patterns of new goods exports to the EU 15. However, his study differs from ours in that he focuses on a different time period (1993-2006 or 19972006, depending on data availability for each particular country) and analyzes a smaller set of goods (760 products, or around $40 \%$ of the number of products in our study) because he uses a less-finely disaggregated decomposition of trade (4-digit level of the SITC classification, instead of the 5-digit disaggregation level we conduct).
} 
trade partners within the EU, we also find that the increases in the share of least-traded exports were consistently larger in the Baltic countries than in the non-Baltic economies. One potential explanation for the lower growth in the least-traded exports in the non-Baltic countries during the 1995-2008 period could be due to the fact that these countries had already enjoyed free access to the EU market dating back from 1992 ${ }^{14}$ Finally, for exports to Russia, the average share of least-traded exports is also higher for the Baltics than for the non-Baltics.

Table 4. Share of the Least-Traded Exports in 2008

(percent)

\begin{tabular}{lcc}
\hline & Baltics & Non-Baltics \\
\hline World & 29.5 & 14.8 \\
EU 15 & 39.8 & 21.8 \\
Germany & 53.1 & 20.5 \\
Nordics & 48.9 & 40.7 \\
Russia & 48.6 & 36.1 \\
\hline
\end{tabular}

Next, we take a deeper look at the data and trace the evolution of the share of leasttraded exports over time. We show the results in Table 5 below. We find that, prior to 2004, both the Baltic countries and the non-Baltic transition economies recorded high growth rates of the share of the least-traded exports to the EU 15. This trend changed after 2004: while there is no marked slowdown in the Baltic growth rate, the non-Baltic growth in leasttraded exports all but stops upon EU accession. Additionally, while growth in exports of least-traded goods to Germany and Russia decelerates for both Baltics and non-Baltics the growth rate in the Baltic countries is significantly higher than what we observed for the nonBaltic countries. The only exception where growth rate patterns are reversed is for exports to the Nordic countries.

Table 5. Growth of the Share of Least-Traded Exports Over Time

(percent, annual average)

\footnotetext{
${ }^{14}$ The Europe Agreements between the EU and the non-Baltic countries came into force in February 1994. However, the market-access and trade-related portions of the Agreements entered into effect in March 1992. We thank an anonymous referee for pointing out this earlier trade agreement between the non-Baltic countries and the EU.
} 


\begin{tabular}{lccrrr}
\hline & \multicolumn{2}{c}{$(1995-2004)$} & & \multicolumn{2}{c}{$(2004-2008)$} \\
\cline { 2 - 3 } \cline { 5 - 6 } & Baltics & Non-Baltics & & Baltics & Non-Baltics \\
\hline World & 8.3 & 3.9 & & 9.2 & 0.6 \\
EU 15 & 10.6 & 9.2 & & 12.9 & 0.4 \\
$\quad$ Germany & 16.7 & 6.9 & & 7.5 & 3.9 \\
$\quad$ Nordics & 14.1 & 11.4 & & 11.6 & 16.4 \\
Russia & 14.2 & 12.9 & & 10.6 & 4.9 \\
\hline
\end{tabular}

Finally, in Table 6 we present the overall growth in exports and the contribution due to the extensive margin. We notice that the overall magnitudes of export growth for the Baltics and the non-Baltic countries are similar, though larger for the non-Baltics. On the other hand, the share of the extensive margin in export growth reveals a contrasting picture: they are consistently higher for the Baltic countries than for the non-Baltic countries. On average, the contribution of the extensive margin in Baltic exports to the EU 15 and Germany is $12 \%$ and $23 \%$ respectively, whereas the corresponding fractions for the non-Baltics are significantly lower, at around 3 to $4 \%$.

Table 6. Export Growth and the Share of the Extensive Margin (1995-2008) (percent)

\begin{tabular}{lccrrr}
\hline & \multicolumn{2}{c}{ Total Export Growth } & & \multicolumn{2}{c}{ Extensive Margin Share } \\
\cline { 2 - 3 } \cline { 5 - 6 } & Baltics & Non-Baltics & & Baltics & Non-Baltics \\
\hline World & 698.3 & 676.0 & & 7.0 & 0.4 \\
EU 15 & 488.2 & 574.6 & & 12.2 & 3.7 \\
$\quad$ Germany & 313.9 & 475.3 & & 23.4 & 3.2 \\
$\quad$ Nordics & 612.5 & 805.8 & & 21.7 & 8.0 \\
Russia & 486.2 & 508.0 & & 12.3 & -1.8 \\
\hline
\end{tabular}

\subsection{The Impact of the Global Financial Crisis on the Extensive Margin}

Finding 7: New goods exports experienced a significant growth slowdown during the GFC across the board. Additionally, the restart in new goods export growth displayed mixed patterns.

In the benchmark analyses, we restricted our attention to the period between 1995 to 2008 , since our interest was on the patterns of new goods margin growth during the various episodes of Baltic trade liberalization reforms, including accession into the EU. By stopping at 2008, we wanted to avoid any sort of distortion created by the GFC.

However, a valid issue to consider is how exports of newly-traded goods behave during severe economic downturns. ${ }^{15}$ We document the behavior of the new goods margin during a

\footnotetext{
$\sqrt[15]{\text { Kehoe and Ruhl }}(2013)$ claim that regular business cycle events are not drivers of growth in the new
} 
period of unprecedented collapse in international trade in the aftermath of the GFC. To do so, we extend the period of analysis from 1995 to 2014. Indeed, the Baltic countries' trade experienced a significant negative swing during the GFC. During the 2009-2010 period, total nominal exports fell by $23 \%$ in Estonia and Latvia and by $31 \%$ in Lithuania. However, the decline in exports was short-lived, since from 2010 onward all three countries recorded increases in nominal exports.

In Table 7, we analyze the share of the least-traded exports during the extended sample period, and decompose the changes in the share of the least-traded goods for three sub-periods: 2005 to 2008 (before the GFC), 2008 to 2011 (a span characterized by trade collapse), and 2011 to 2014 (when trade recovers). We find that in comparison to the period prior to the GFC, growth in the share of least-traded exports shows a noticeable slowdown. For example, the share of the least-traded exports to the EU increased by 1.1 percentage points between 2008 and 2011, which is one tenth of the magnitude observed during the period 2005 and 2008. For all other export destinations, we observe similar patterns of deceleration in the growth of the least-traded export shares. However, for the period between 2011 and 2014, EU-bound exports of the least-traded goods rebounded, as their share increased by 3.6 percentage points. For the individual EU members and Russia, the patterns are mixed. On the one hand, exports to the Nordics followed a similar trend to the EU as a whole, with the share of the least-traded exports resuming growth. On the other hand, the share of least-traded exports to Germany and Russia showed no change or even a decrease during the post-GFC period.

Table 7. Changes in the Share of Least-Traded Exports (2005-2014) (percentage points)

\begin{tabular}{lccc}
\hline & $(2005-2008)$ & $(2008-2011)$ & $(2011-2014)$ \\
\hline World & 4.6 & 3.8 & 2.3 \\
EU 15 & 10.7 & 1.1 & 3.6 \\
Germany & 9.1 & 3.7 & 0.0 \\
Nordics & 11.5 & 3.1 & 6.0 \\
Russia & 8.7 & 6.2 & -0.4 \\
\hline
\end{tabular}

goods margin by comparing trade among NAFTA countries with United States exports to Germany, Japan and the UK (or non-NAFTA countries) between 1989 and 1999. Since no significant trade liberalization or structural reform took place between the United States and the non-NAFTA countries, regular business cycles would not impact the extensive margin in trade. 


\section{Discussion of Results}

Our results indicate that the Baltic countries increased both their imports and exports of least-traded goods substantially. What are the implications of such trends beyond simply the expansion of trade? As we noted in the Introduction, increases in the import variety mix entail non-negligible welfare effects. Besides the results found by Broda and Weinstein (2006) for the United States, Chen and Ma (2012) also quantify that, for the case of China, the welfare gains resulting from increases in import variety between 1997 and 2008 are equivalent to $4.9 \%$ of GDP, while Chen and Jacks (2012) find that the increase in import varieties between 1988 and 2007 is associated with Canadian consumers' welfare gains as large as $28 \%$. Thus, increases in the imports extensive margin have also significant welfare implications and ignoring them would lead to systematically understate the gains from trade. We expect that the Baltic consumers also experienced large welfare gains due to the increases in the imports of previously least-traded goods observed in those countries.

Additionally, our findings also document that the Balitcs' increases in their exports of least-traded goods were even larger than their imports counterparts. Moreover, the Baltics' increases in the exports new goods largely exceeded the increases recorded by other transition economies. In a recent article, Feenstra and Kee (2008) employ a variant of Melitz's monopolistic competition model to show that, for a sample of 44 countries, the total increase in export variety is associated with an average 3.3\% productivity gain per year for exporters over the 1980-2000 period, and that export variety can explain a substantial fraction of the within-country variation in productivity. Although the link between productivity gains and least-traded exports is beyond the scope of this study, we conduct simple back-of-theenvelope calculations to explore whether the larger variety of export products is associated with higher productivity gains for the case of the Baltic countries. To measure productivity growth during the 1995-2008 period, we construct labor productivity series using data from the World Input-Output Database (WIOD) ${ }^{16}$ In Table 8, we present the share of least-traded exports to the world and the growth rate of labor productivity for the Baltic countries and for the transition countries we considered in Section 5. We find that, on average, the Baltic increases in labor productivity were approximately twice as large as the observed values for the non-Baltic counterparts. Moreover, Estonia, which among the Baltic countries recorded the largest increase in least-traded exports, also experienced the largest increase in labor productivity. On the other hand, Lithuania, which was the Baltic country that recorded the smallest increases in least-traded exports also displayed the smallest gains in labor produc-

\footnotetext{
${ }^{16}$ Our definition of productivity differs from that in Feenstra and Kee (2008) since we look at the evolution of labor productivity, whereas they focus on total factor productivity.
} 
tivity. ${ }^{17}$ While a more precise study is needed, this preliminary analysis seems to suggest that increases in least-traded exports are accompanied by increases in labor productivity, thus underscoring the importance of the new goods margin.

Table 8. Least-traded Exports and Labor Productivity
(percent)

\section{Conclusion}

In this article, we analyze the behavior of the extensive margin of trade for the three Baltic countries between 1995 and 2008, a period that coincides with episodes of market transition and accession into the European Union. More specifically, we assess by how much the overall growth in Baltic exports and imports was due to goods that had previously not been traded.

There is a considerable debate about the relative roles of the extensive and intensive margins in trade growth: Hummels and Klenow (2005) concludes that the extensive margin is the primary driver of export growth while Helpman et al. (2008) and Besedeš and Prusa (2011) found that the intensive margin plays the dominant role ${ }^{18}$ Our paper contributes to the literature by disentangling the roles of the extensive and intensive margins in economies that were previously closed to trade and quickly opened their foreign sectors. Our contribution is not only limited to documenting the driving forces of the new goods margin, but also addresses important policy implications by identifying new trading opportunities.

We find that the new goods margin played a crucial role in the growth of Baltic trade. Indeed, by 2008, nearly half of total exports bound to and almost a quarter of total imports

\footnotetext{
${ }^{17}$ Note that the same positive relationship between share of least-traded exports and labor productivity holds for the non-Baltic countries.

${ }^{18}$ It is worthwhile, however, to note that these terminologies do not necessarily have the same meaning across papers. In some cases, the extensive margin refers to the number of exporters for a given good (for example, as in Chaney, 2008), while in other cases it refers to the country-pair specific export relationship (as in Rose, 2004). In our paper, by extensive margin we refer to the trade growth of goods that had not been traded before or been traded in low volumes.
} 
coming from the Baltic countries' main trade partners could be accounted for by the goods that previously had been not traded or traded in very low volumes. This robust growth in new goods trade is quite a unique characteristic of the Baltic economies: when we compare our results for the Baltic countries with a sample of transition countries in Central Europe with a similar magnitude of overall export growth, we find markedly smaller increases in the new goods margin for the non-Baltic economies. In addition, while the Baltic economies recorded similar growth rates along the extensive margin until 2008, the Global Financial Crisis led to a sizable decline in the new goods margin across the region.

The Baltic countries, and in particular Estonia, are usually portrayed as exemplary models of trade liberalization. As we have documented in this paper, they outpaced their regional peers in growing the imports and exports of the goods that initially were traded in low volumes. An interesting study that could be motivated from our article could feature a model that quantitatively assesses the role of trade liberalization reforms in expanding the new goods margin, applied to compare the different experiences of the transition economies. Similarly, most of the reforms that opened the Baltic economies were implemented when the countries were not yet members of the EU. By accessing the Union, the Baltics adopted its Commercial Common Policy and relinquished their abilities to independently liberalize their economies even further. Thus, another interesting research project could focus on tracing the response of the extensive margin for the Baltic and other Central and the Eastern European countries to the new free trade agreements the EU has recently finalized or is currently in the process of negotiating. 


\section{Appendix 1: Least-Traded Goods Patterns for Estonia, Latvia and Lithuania}

Figure A.1. Composition of Estonian Exports and Imports
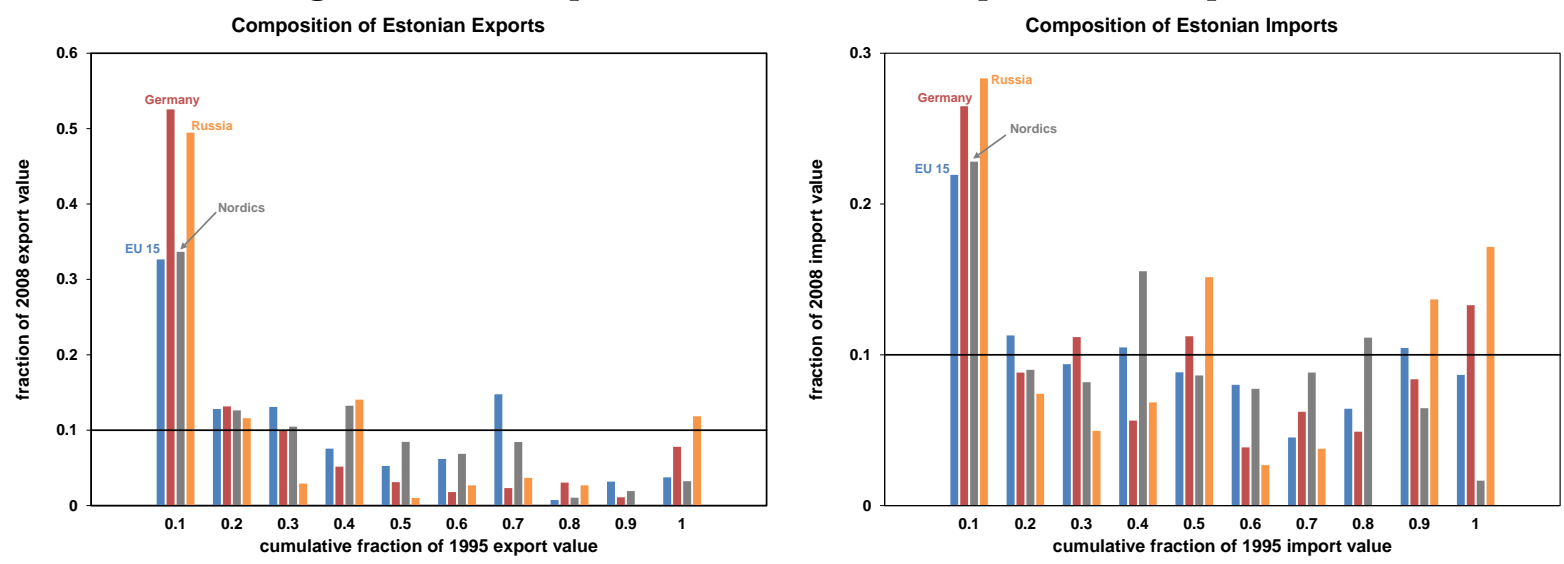

Figure A.2. Composition of Latvian Exports and Imports
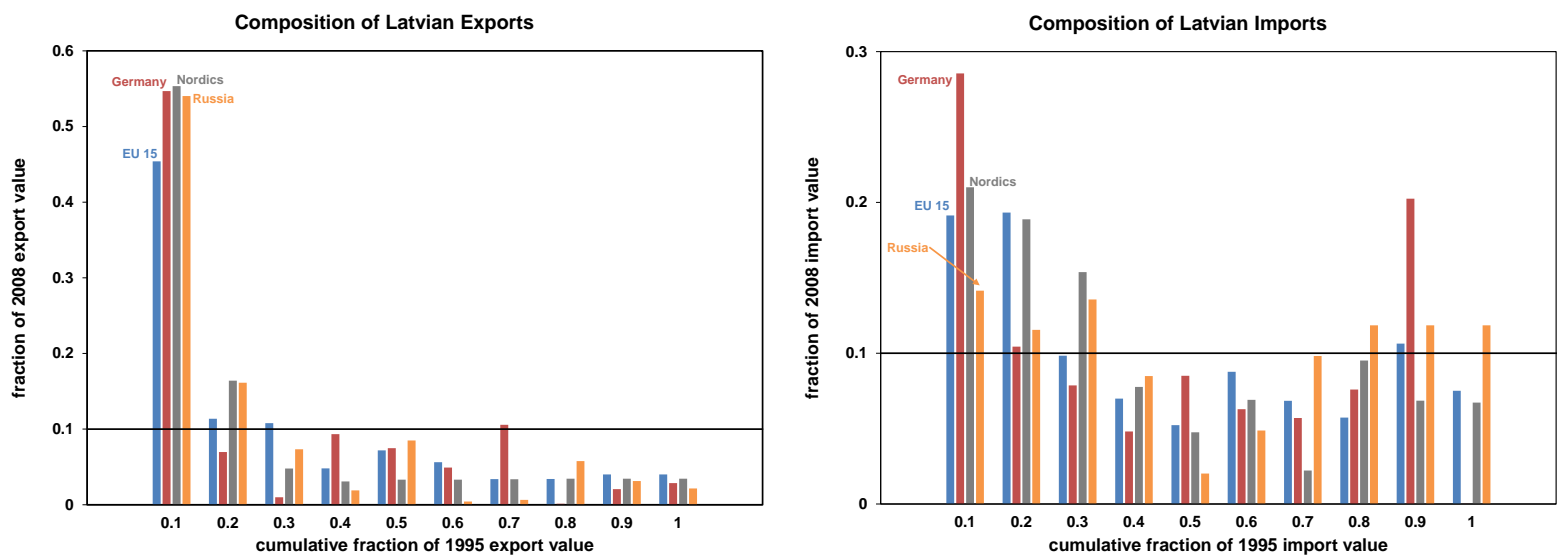

Figure A.3. Composition of Lithuanian Exports and Imports
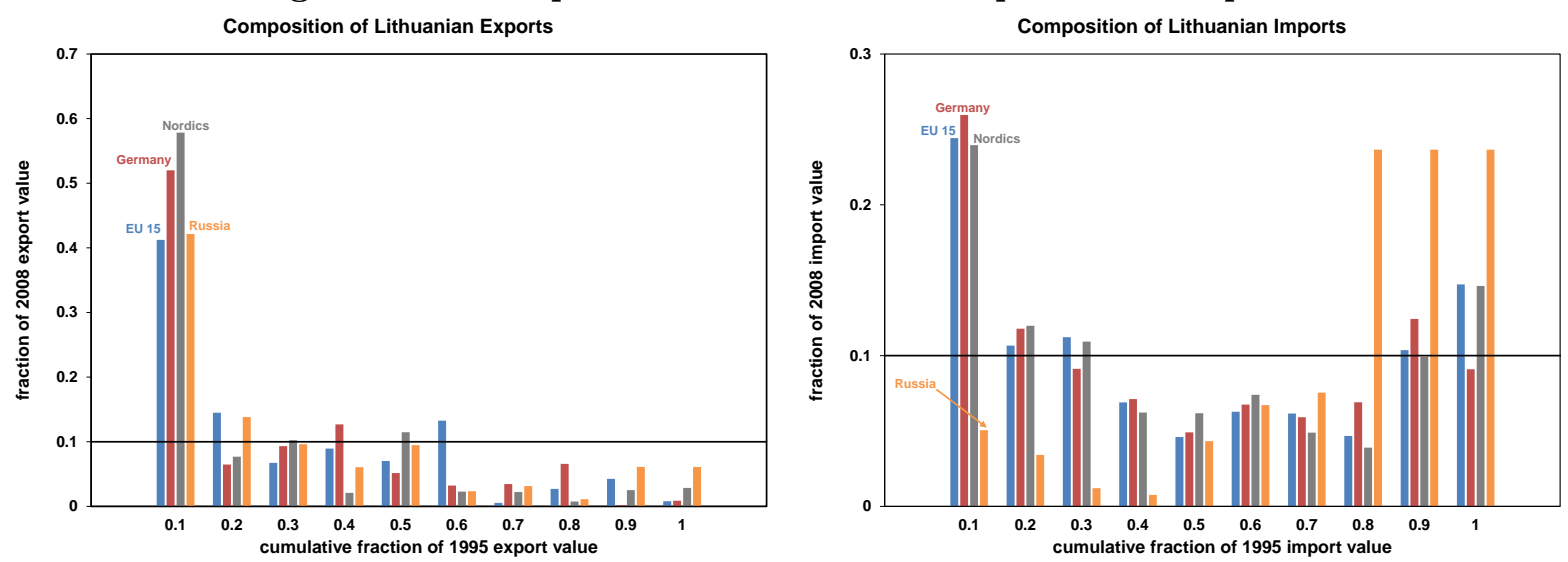
Table A.1. Fraction of Estonian, Latvian and Lithuanian Least-traded Exports to Main Trade Partners

\begin{tabular}{|c|c|c|c|c|c|c|c|c|c|c|c|c|}
\hline \multirow[b]{2}{*}{ Year } & \multicolumn{4}{|c|}{ Estonia } & \multicolumn{4}{|c|}{ Latvia } & \multicolumn{4}{|c|}{ Lithuania } \\
\hline & EU 15 & Germany & Nordics & Russia & EU 15 & Germany & Nordics & Russia & EU 15 & Germany & Nordics & Russia \\
\hline 1995 & 0.10 & 0.10 & 0.10 & 0.10 & 0.10 & 0.10 & 0.10 & 0.10 & 0.10 & 0.10 & 0.10 & 0.10 \\
\hline 1996 & 0.08 & 0.07 & 0.09 & 0.10 & 0.10 & 0.07 & 0.19 & 0.10 & 0.08 & 0.08 & 0.12 & 0.08 \\
\hline 1997 & 0.08 & 0.07 & 0.08 & 0.06 & 0.10 & 0.09 & 0.18 & 0.13 & 0.10 & 0.08 & 0.14 & 0.09 \\
\hline 1998 & 0.10 & 0.12 & 0.09 & 0.15 & 0.13 & 0.12 & 0.20 & 0.18 & 0.15 & 0.13 & 0.21 & 0.13 \\
\hline 1999 & 0.12 & 0.20 & 0.09 & 0.17 & 0.13 & 0.15 & 0.23 & 0.32 & 0.19 & 0.19 & 0.25 & 0.26 \\
\hline 2000 & 0.11 & 0.39 & 0.07 & 0.21 & 0.17 & 0.22 & 0.25 & 0.28 & 0.19 & 0.21 & 0.37 & 0.20 \\
\hline 2001 & 0.12 & 0.28 & 0.09 & 0.31 & 0.20 & 0.29 & 0.28 & 0.25 & 0.20 & 0.21 & 0.40 & 0.18 \\
\hline 2002 & 0.14 & 0.43 & 0.14 & 0.26 & 0.22 & 0.31 & 0.29 & 0.26 & 0.22 & 0.26 & 0.39 & 0.14 \\
\hline 2003 & 0.15 & 0.37 & 0.16 & 0.26 & 0.24 & 0.35 & 0.32 & 0.32 & 0.25 & 0.29 & 0.44 & 0.19 \\
\hline 2004 & 0.19 & 0.45 & 0.19 & 0.32 & 0.30 & 0.37 & 0.37 & 0.42 & 0.25 & 0.38 & 0.43 & 0.25 \\
\hline 2005 & 0.25 & 0.46 & 0.22 & 0.43 & 0.32 & 0.41 & 0.43 & 0.48 & 0.31 & 0.45 & 0.47 & 0.29 \\
\hline 2006 & 0.25 & 0.47 & 0.23 & 0.49 & 0.35 & 0.47 & 0.50 & 0.50 & 0.34 & 0.45 & 0.49 & 0.34 \\
\hline 2007 & 0.30 & 0.50 & 0.32 & 0.55 & 0.35 & 0.46 & 0.47 & 0.48 & 0.40 & 0.52 & 0.52 & 0.39 \\
\hline 2008 & 0.33 & 0.53 & 0.34 & 0.49 & 0.45 & 0.55 & 0.55 & 0.54 & 0.41 & 0.52 & 0.58 & 0.42 \\
\hline
\end{tabular}

Table A.2. Fraction of Estonian, Latvian and Lithuanian Least-traded Imports from Main Trade Partners

\begin{tabular}{|c|c|c|c|c|c|c|c|c|c|c|c|c|}
\hline \multirow[b]{2}{*}{ Year } & \multicolumn{4}{|c|}{ Estonia } & \multicolumn{4}{|c|}{ Latvia } & \multicolumn{4}{|c|}{ Lithuania } \\
\hline & EU 15 & Germany & Nordics & Russia & EU 15 & Germany & Nordics & Russia & EU 15 & Germany & Nordics & Russia \\
\hline 1995 & 0.10 & 0.10 & 0.10 & 0.10 & 0.10 & 0.10 & 0.10 & 0.10 & 0.10 & 0.10 & 0.10 & 0.10 \\
\hline 1996 & 0.10 & 0.11 & 0.09 & 0.07 & 0.10 & 0.11 & 0.09 & 0.08 & 0.09 & 0.08 & 0.08 & 0.07 \\
\hline 1997 & 0.09 & 0.09 & 0.08 & 0.05 & 0.09 & 0.11 & 0.08 & 0.08 & 0.09 & 0.08 & 0.08 & 0.06 \\
\hline 1998 & 0.11 & 0.14 & 0.09 & 0.12 & 0.11 & 0.15 & 0.10 & 0.13 & 0.11 & 0.10 & 0.12 & 0.08 \\
\hline 1999 & 0.12 & 0.19 & 0.10 & 0.23 & 0.13 & 0.17 & 0.12 & 0.18 & 0.13 & 0.13 & 0.14 & 0.08 \\
\hline 2000 & 0.14 & 0.20 & 0.12 & 0.27 & 0.13 & 0.19 & 0.14 & 0.18 & 0.16 & 0.13 & 0.13 & 0.07 \\
\hline 2001 & 0.14 & 0.19 & 0.12 & 0.34 & 0.13 & 0.19 & 0.13 & 0.15 & 0.13 & 0.13 & 0.15 & 0.08 \\
\hline 2002 & 0.16 & 0.17 & 0.12 & 0.38 & 0.14 & 0.19 & 0.14 & 0.20 & 0.17 & 0.14 & 0.22 & 0.08 \\
\hline 2003 & 0.14 & 0.18 & 0.13 & 0.28 & 0.16 & 0.20 & 0.17 & 0.16 & 0.18 & 0.13 & 0.30 & 0.09 \\
\hline 2004 & 0.19 & 0.24 & 0.20 & 0.22 & 0.18 & 0.22 & 0.23 & 0.17 & 0.16 & 0.17 & 0.19 & 0.09 \\
\hline 2005 & 0.20 & 0.22 & 0.21 & 0.23 & 0.17 & 0.26 & 0.17 & 0.19 & 0.16 & 0.18 & 0.19 & 0.06 \\
\hline 2006 & 0.23 & 0.26 & 0.25 & 0.24 & 0.16 & 0.24 & 0.16 & 0.16 & 0.20 & 0.19 & 0.20 & 0.07 \\
\hline 2007 & 0.24 & 0.28 & 0.28 & 0.18 & 0.18 & 0.24 & 0.17 & 0.16 & 0.21 & 0.19 & 0.20 & 0.11 \\
\hline 2008 & 0.22 & 0.26 & 0.23 & 0.28 & 0.19 & 0.29 & 0.21 & 0.14 & 0.24 & 0.26 & 0.24 & 0.05 \\
\hline
\end{tabular}

Table A.3. Export Growth and the Share of the Extensive Margin (1995-2008) (percent)

\begin{tabular}{crrrrrrr}
\hline & \multicolumn{3}{c}{ Total Export Growth } & & \multicolumn{3}{c}{ Share of Extensive Margin } \\
\cline { 2 - 3 } \cline { 6 - 8 } & Estonia & Latvia & Lithuania & & Estonia & Latvia & Lithuania \\
\hline EU 15 & 468.0 & 457.3 & 539.3 & & 7.5 & 14.4 & 14.8 \\
Germany & 330.3 & 283.9 & 327.6 & & 21.5 & 14.3 & 34.4 \\
Nordics & 486.1 & 448.4 & 902.9 & & 4.7 & 38.7 & 21.7 \\
Russia & 563.5 & 186.5 & 708.5 & & 17.0 & 10.0 & 9.9 \\
\hline
\end{tabular}

Table A.4. Import Growth and the Share of the Extensive Margin (1995-2008) (percent)

\begin{tabular}{crrrrrrr}
\hline & \multicolumn{3}{c}{ Total Import Growth } & & \multicolumn{3}{c}{ Share of Extensive Margin } \\
\cline { 2 - 3 } \cline { 7 - 8 } & Estonia & Latvia & Lithuania & & Estonia & Latvia & Lithuania \\
\hline EU 15 & 360.5 & 660.9 & 766.0 & & 5.0 & 2.0 & 4.8 \\
Germany & 745.3 & 642.5 & 603.1 & & 3.6 & 1.9 & 5.5 \\
Nordics & 169.0 & 371.3 & 621.4 & & 2.6 & 1.8 & 1.7 \\
Russia & 252.8 & 430.1 & 830.2 & & -29.3 & -9.6 & -13.7 \\
\hline
\end{tabular}




\section{Appendix 2: Using an Alternative Threshold to Define Least-Traded Goods}

In our analysis, we followed the KR methodology and defined least-traded goods to be specific for each country pair. In this section, we examine whether the qualitative findings we previously uncovered change when we use an alternative cutoff to define least-traded goods. Specifically we label a good as least-traded if the average trade volume in the first three years of the sample is less than $\$ 50,000$. This is the same approach used in Evenett and Venables (2002).

The results for the share of least-traded exports and imports in 2008 are shown in Table A.5. As we use a fixed-value threshold, the share of least-traded goods in 1995 is smaller for larger trade partners (such as EU 15) as there are many fewer goods that are traded in volumes smaller than $\$ 50,000$. Despite the differences in the initial shares, we find that least-traded exports and imports also show significant growth, as shown by their shares in 2008. In addition, the magnitude of the growth on the import side is also at most half the magnitude of the export counterpart, which coincides with our previous findings. Thus, we confirm that Findings 1 and 3 still hold under the alternative methodology. We also note that the ranking of increases in the shares between 1995 and 2008 using the alternative cutoff remains the same as the one when we use the KR methodology. That is, the largest gain in the share of least-traded goods (in both exports and imports) takes place with Germany, followed by the Nordics, Russia, and EU 15.

Table A.5. Shares of Least-Traded Goods Using a \$50,000 Cutoff

\begin{tabular}{lrrrrr}
\multicolumn{4}{c}{ (percent) } & & \multicolumn{2}{c}{} \\
\hline & \multicolumn{2}{c}{ Exports } & & \multicolumn{2}{c}{ Imports } \\
\cline { 2 - 3 } \cline { 6 - 6 } & 1995 & 2008 & & 1995 & 2008 \\
\hline EU 15 & 1.0 & 16.4 & & 0.5 & 7.1 \\
Germany & 2.9 & 36.8 & & 2.5 & 15.2 \\
Nordics & 2.3 & 31.5 & & 2.6 & 12.3 \\
Russia & 2.4 & 25.4 & & 3.1 & 9.0 \\
\hline
\end{tabular}

Next, we analyze the evolution over time of the share of least-traded goods under the alternative threshold. Those trends are depicted in Figure A.4. Similar to our findings in Section 5, we confirm that the share of least-traded Baltic exports to their main trade partners exhibits increases that coincide with the major trade liberalization reforms. We also confirm that least-traded exports to Russia stagnates around the late 1990s and early 2000s, followed by a rebound period that coincides with the Baltic accession into the EU. For the case of imports, we find that while the share of least-traded imports from the EU members shows sustained growth throughout the 1995-2008 period, the share of least-traded imports from Russia experiences a steep decline starting from 2003. These findings concur 
with Findings 2 and 4 in Section 5.

Figure A.4. Least-traded Goods Trade (1995-2008) Using a \$50,000 Cutoff
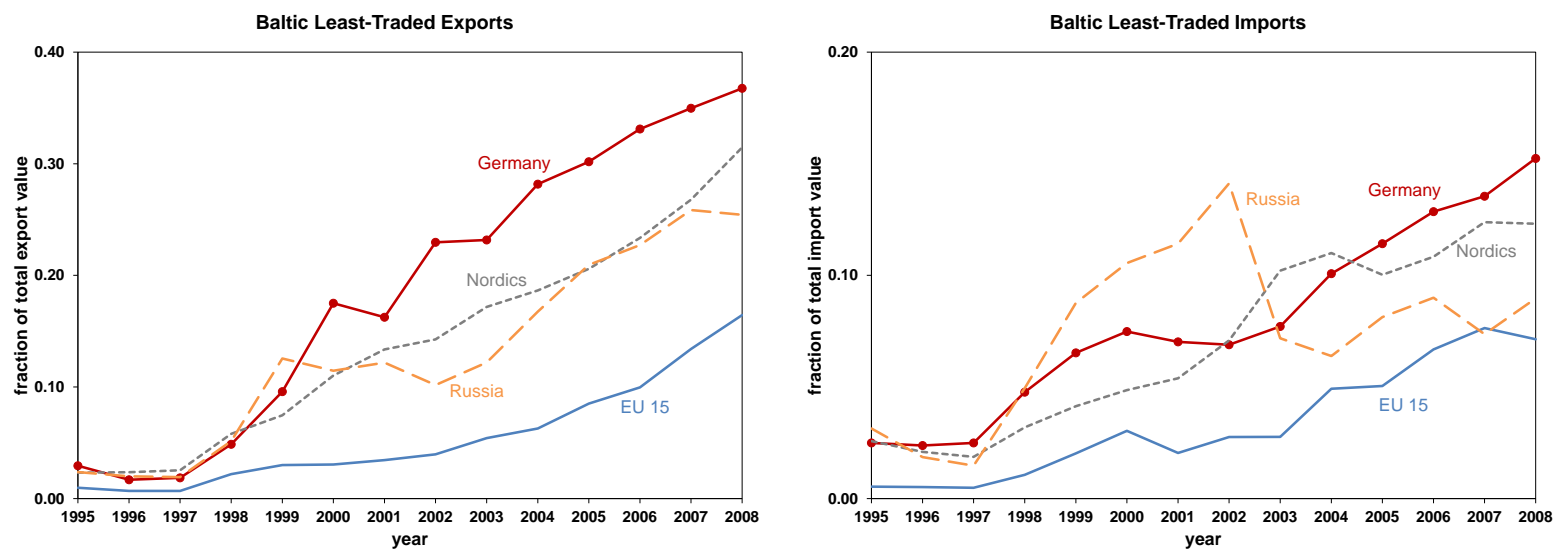


\section{References}

Amarsanaa, Chingunjav, Kurokawa, Yoshinori, 2012, The extensive margin of international trade in a transition economy: the case of Mongolia. Tsukuba Economics Working Paper No. 2011-005.

Arkolakis, Costas. 2010. Market penetration costs and the new consumers margin in international trade. Journal of Political Economy, Vol. 118, pp. 1151-1199.

Bems, Rudolfs, Jönsson Hartelius, Kristian, 2006. Trade deficits in the Baltic States: how long will the party last? Review of Economic Dynamics, Vol. 9, No. 1, pp. 179-209.

Bernard, Andrew B., Jensen, J. Bradford, Schott, Peter K., 2003. Falling trade costs, heterogeneous firms, and industry dynamics. National Bureau of Economic Research Working Paper 9639

Broda, Christian, Weinstein, David E., 2006. Globalization and the gains from variety. Quarterly Journal of Economics, Vol. 121, No. 2, pp. 541-585.

Besedeš, Tibor, Prusa, Thomas J., 2011. The role of extensive and intensive margins and export growth. Journal of Development Economics, Vol. 96, pp. 371-379.

Chaney, Thomas, 2008. Distorted gravity: the intensive and extensive margins of international trade. American Economic Review, Vol. 98, pp.1707-21.

Chen, Bo, Jacks, David, 2012. Trade, Variety and Immigration. Economics Letters, Vol. 117, No.1, pp. 243-246.

Chen, Bo, Hong, Ma, 2012. Import variety and welfare gain in China. Review of International Economics, Vol. 20, No.4, pp. 807-820.

Dalton, John T., 2014. The new goods margin in Japanese-Chinese trade. Japan and the World Economy, Vol. 31, pp. 8-13.

Dalton, John T., 2016. EU enlargement and the new goods margin in Austrian Trade. Open Economies Review. In press.

Evenett, Simon J., Venables, Anthony J., 2002. Export growth in developing countries: market entry and bilateral trade flows. Manuscript, Oxford University.

Feenstra, Robert C., 1994. New product varieties and the measurement of international prices. American Economic Review, Vol. 84, pp.157-177.

Feenstra, Robert C., Kee, Hiau Looi, 2008. Export variety and country productivity: estimating the monopolistic competition model with endogenous productivity. Journal of International Economics, Vol. 74, No. 2, pp.500-518. 
Feldmann, Magnus, 2001. The fast track from the Soviet Union to the world economy: external liberalization in Estonia and Latvia. Government and Opposition, Vol. 36, pp. $537-558$.

Feldmann, Magnus, Sally, Razeen, 2002. From the Soviet Union to the European Union: Estonian trade policy, 1991-2000. World Economy, Vol. 25, pp. 79-106.

Helpman, Elhanan, Melitz, Marc, Rubinstein, Yona, 2008. Estimating trade flows: trading partners and trading volumes. Quarterly Journal of Economics, Vol. 123, No. 2, pp.441487.

Hloušek, Miroslav, 2010. New goods margin in international trade: empirical analysis for Visegrad countries. In Challenges for Analysis of the Economy, the Businesses, and Social Progress. Szeged: Unidocument Kft., pp. 121-132.

Hummels, David, Klenow, Peter J., 2005. The variety and quality of a nation's exports. American Economic Review, Vol. 95, No. 3, pp. 704-723.

Kehoe, Timothy J., Ruhl, Kim J., 2013. How important is the new goods margin in international trade? Journal of Political Economy, Vol. 121, No. 2, pp. 358-392.

Melitz, Marc J., 2003. The impact of trade on intra-industry reallocations and aggregate industry productivity. Econometrica, Vol. 71, pp. 1695-1725.

Pautola-Mol, Nina, 2003. Preferential trade agreements: specific aspects of EU-Baltic trade integration. In The Road to the European Union, Volume 2: Estonia, Latvia and Lithuania, edited by Vello Pettai and Jan Zielonka. Manchester: Manchester University Press, pp. 231-254.

Rose, Andrew K., 2004. Do we really know that the WTO increases trade? American Economic Review, Vol. 94, No. 1, pp. 98-114.

Ruhl, Kim J., 2008. The international elasticity puzzle. Mimeo, University of Texas at Austin.

Sandrey, Ron, Van Seventer, Dirk, 2004. Has the New Zealand/Australian Closer Economic Relationship (CER) been trade widening or deepening? African Development and Poverty Reduction: The Macro-Micro Linkage Forum Paper.

Vilpišauskas, Ramūnas, 1998. Lithuania's membership in the European Union: possible effects on Lithuania's external trade policy. Lithuanian Foreign Policy Review, Vol. 1(1), pp. 63-85.

Vilpišauskas, Ramūnas, 2003. Regional integration in Europe: analyzing intra-Baltic economic cooperation in the context of European integration. In The Road to the European Union, Volume 2: Estonia, Latvia and Lithuania, edited by Vello Pettai and Jan Zielonka. Manchester: Manchester University Press, pp. 163-204. 